\title{
Argyreia gyrobracteata Traiperm \& Chitchak (Convolvulaceae): A new record to the flora of Vietnam
}

\author{
Binh Duc TRAN, Bach The TRAN, Van Hai DO, Quang Hong BUI, Son Hoang DOAN, \\ Han Ngoc LE, Thuy Thu NGUYEN ${ }^{1}$ and Sangmi EUM ${ }^{1^{*}}$ \\ Institute of Ecology and Biological Resources, Vietnam Academy of Science and Technology, Hanoi 10000, Viet Nam \\ ${ }^{1}$ Korea Research Institute of Bioscience and Biotechnology, Daejeon 34141, Korea \\ (Received 28 May 2020; Revised 14 July 2020; Accepted 17 September 2020)
}

\begin{abstract}
Argyreia gyrobracteata Traiperm \& Chitchak (Convolvulaceae) is newly recorded in Vietnam. It is similar to A. mekongensis Gagnep \& Courch in having a white campanulate corolla but differs from that species by having whitish surface of the abaxial leaf, narrowly lanceolate or linear-oblong, curly, rolled up the bract with a longer length of the petiole and a shorter pedicel. It was previously known only in Thailand, but was recently found in Lam Dong Province, Vietnam, for the first time. The present study provides a detailed description, colorful photos and the distribution of the species. Furthermore, a comparison of the diagnostic characters between this species and a related species in Vietnam, A. mekongensis Gagnep \& Courch, is provided.
\end{abstract}

Keywords: Argyreia gyrobracteata, new record, Convolvulaceae, Vietnam

The genus Argyreia Lour. (Gagnepain and Courchet, 1915), consists of 135 species distributed from Madagascar, Tropical \& Subtropical Asia to N. Queensland (Mabberley, 2017; Chitchak et al., 2018). Thailand and Myanmar are species-rich countries having 37 species each (Traiperm and Staples, 2016; Traiperm et al., 2019), followed by 22 species in China (Fang and Staples, 1995), 18 species in Malaysia (Kiew et al., 2015), 16 species in Laos PDR (Staples et al., 2014) and 5 species in Cambodia (Cho et al., 2016). Argyreia is a genus of herbaceous climbers or scandent shrubs or lianas, flowers in cymes or capitula, corolla 5-lobed and fruit indehiscent or berry (Staples and Traiperm, 2010). It is similar to Ipomoea morphologically but differs in its fruit. The fruit of the former is indehiscent, fleshy, or mealy berries, whereas that of the latter is a dehiscent dry capsule (Kiew et al., 2015). Argyreia is a problematic genus in Convolvulaceae due to morphological complexity but no precise revisions or its monograph are available up to date, especially in Southeast Asia which is species rich for the genus (Traiperm and Staples, 2013, 2016; Shalini et al., 2017; Traiperm et al., 2019).

So far, sixteen species are recognized from Vietnam but again, comprehensive research including nomenclature review should be taken to confirm the actual number of species for the genus. An account of Argyreia in this paper relies on the foundation of Pham (1999) and Staples (2018) which has been accepted by taxonomists in Vietnam. During our regular survey work in Lam Dong Province, southern highland of Vietnam, we collected several specimens of Convolvulaceae. The genus is distributed throughout Vietnam and seven species have been reported from Lam Dong, A. mollis, A. osyrensis, A. lanceolata, A. laotica, A. longipes, A. mekongensis, and A. monosperma. Among these species, our specimen was morphologically similar to A. mekongensis (Table 1). On the basis of available literatures (Pham, 1999; Chitchak et al., 2018; Staples, 2018) and carefully checking herbarium specimens of Argyreia in Herbarium of the Institute of Ecology and Biological Resource (HN) Hanoi, finally it was identified as A. gyrobracteata Traiperm \& Chitchak, a first record from Vietnam (Fig. 1). $A$. gyrobracteata differs from $A$. mekongensis by the whitish surface of its abaxial leaf, narrowly lanceolate or linear-oblong, curly, rolled up bract, longer length of the petiole and shorter pedicel. Previously A. gyrobracteata had been reported only

\footnotetext{
*Author for correspondence: sangeum@gmail.com
} 


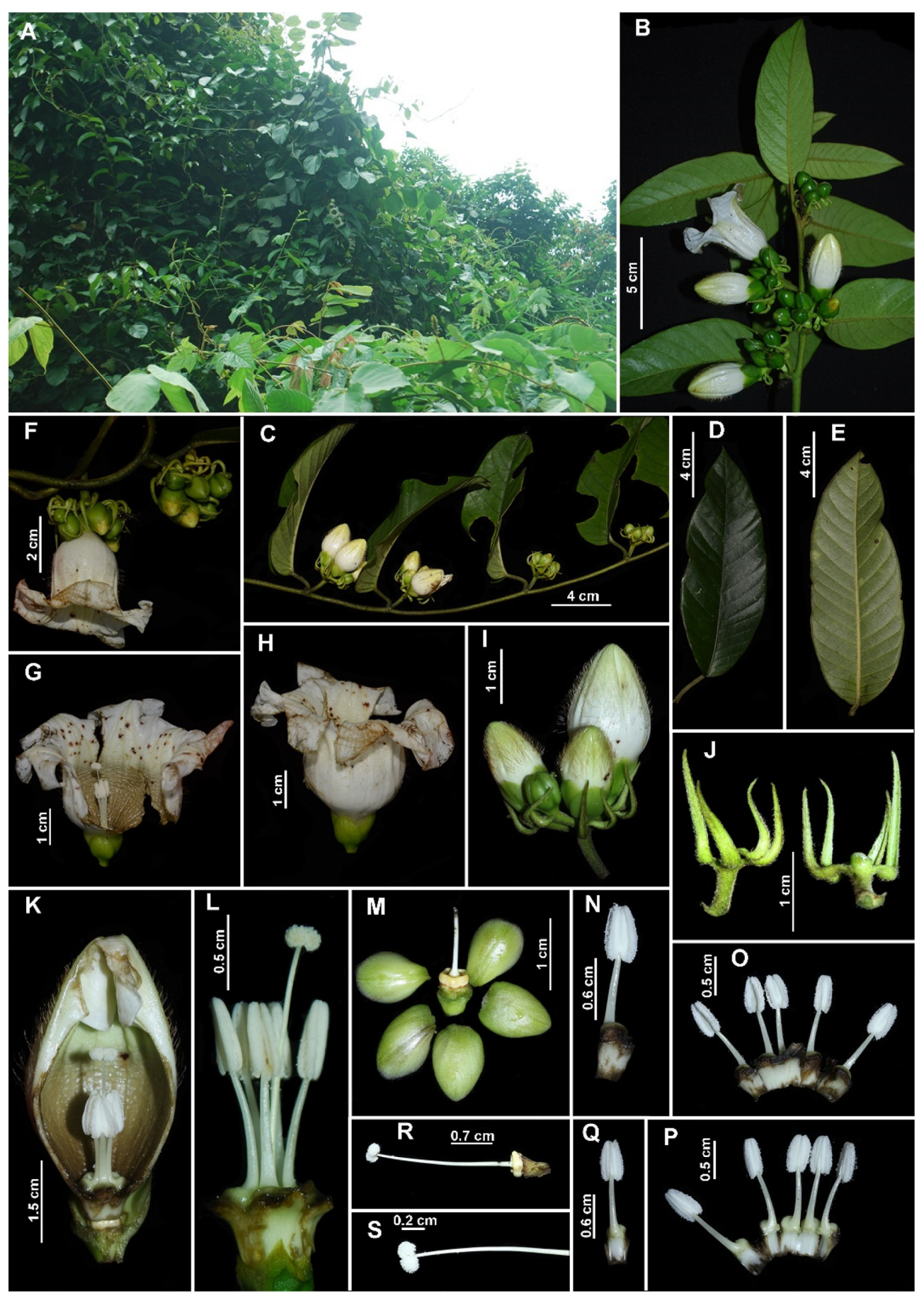

Fig. 1. Argyreia gyrobracteata Traiperm \& Chitchak. A. Habit. B, C, F, I. Flower with inflorescences. D. Adaxial leaf. E. Abaxial leaf. G, H. Flowers. J. Adaxial (left) and abaxial (right) bracts. K. Longitudinal section of flower buds. L. Filaments and style. M. Sepals. N-O. Front view of stamen. Q-P. Side view of stamen. R-S. Pistil. Photos by T.T.Bach and T.D.Binh.

in two different districts, Trakan Phut Phon and Sirindhorn in Thailand, the latter being located close to the border of Lao PDR (Chitchak et al., 2018) (Fig. 2). Interestingly, up to now, no record for A. gyrobracteata has been reported from Lao
PDR and Cambodia, two countries located between Thailand and Vietnam (Newman et al., 2007; Cho et al., 2016). Therefore, a further study for A. gyrobracteata is needed to explain its discontinuous distribution in these regions. Here, 
Table 1. Morphological comparison of Argyreia gyrobracteata and A. mekongensis.

\begin{tabular}{ccc}
\hline \hline Characters & A. gyrobracteata & A. mekongensis \\
\hline Habit & Climber and prostrate & Woody twiner \\
Leaf blade shape & Ovate or ovate-elliptic & Elliptic to broadly oblong \\
Leaf blade size & $10.3-14.5 \times 4.6-6.5 \mathrm{~cm}$ & $7.0-12 \times 3.0-4.0 \mathrm{~cm}$ \\
Abaxial leaf surface & Whitish, sericeous & Densely greyish tawny pubescent \\
No. of secondary veins & $9-15$ & $6-12$ \\
Petiole length $(\mathrm{cm})$ & $1.3-2.1$ & $1.0-1.2$ \\
Pedicels length $(\mathrm{mm})$ & $0.4-0.6$ & 10 \\
Bract shape & Narrowly lanceolate or linear-oblong & Lanceolate or ovate-cuspidate \\
Bract size $(\mathrm{cm})$ & $1.5-2.5 \times 0.3-0.7$ & $2.0 \times 0.8$ \\
Bract orientation & Curly, rolled up & Straight \\
Outer sepal size $(\mathrm{cm})$ & $0.7-1 \times 0.4-0.6$ & $0.8-1.3 \times 0.6-0.7$ \\
Inner sepal size $(\mathrm{cm})$ & $0.7 \times 0.6$ & $0.9-1.0 \times 0.7-1.0$ \\
Corolla tube length $(\mathrm{cm})$ & $4.1-4.3$ & $4.0-4.7$ \\
\hline
\end{tabular}

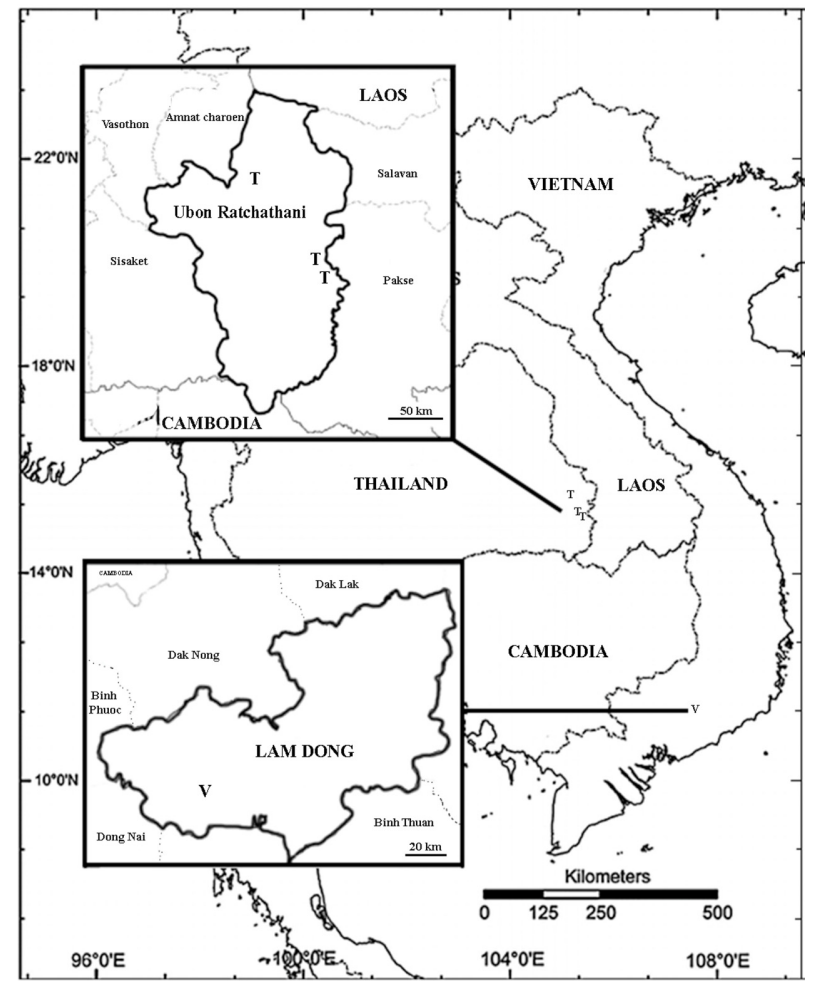

Fig. 2. Distribution map of Argyreia gyrobracteata Traiperm \& Chitchak in Lam Dong Province, Vietnam (V) and two accessions at Trakan Phut Phon and Sirindhorn in Ubon Ratchathani province, Thailand (T).

we provide a detailed description, habitat, distribution, color photographs, and comparison table.

\section{Taxonomic Treatment}

Argyreia gyrobracteata Traiperm \& Chitchak. Botany. 96: 217-233, 2018 (Fig. 1)-TYPE: THAILAND. Ubon Ratchathani, Sirindhorn district, Chong Mek subdistrict, in the edge of dipterocarp forest, $15^{\circ} 07^{\prime} 20.8^{\prime \prime} \mathrm{N}, 105^{\circ} 28^{\prime} 02.1^{\prime \prime} \mathrm{E}, 20$ Aug 2016, P. Rattanakrajang, N. Chitchak \& P. Traiperm 110 (holotype BKF; isotypes $\mathrm{K}, \mathrm{QBG}$ ).

Description (based on the specimens from Vietnam cited below): Perennial creepers. Stems 5-7 m long; young branches yellowish pubescent. Leaves simple, entire; petiole $1.3-2.1 \mathrm{~cm}$ long, pubescent; leaf blade ovate or ovate-elliptic, 10.3-14.5 cm long, 4.6-6.5 cm wide; base obtuse, margin entire, apex acute to obtuse, adaxial surface green, glabrous, glabrescent or hairy on midrib and secondary veins; abaxial surface whitish, sericeous, secondary veins 9-15 pairs. Inflorescences axillary, pendulous, cymose, 4-6-flowered; peduncle $0.7-1.4 \mathrm{~cm}$ long, hairy; bracts 3 or 4 , twisted, rolled up, subequal, narrowly lanceolate or linear-oblong, middle bract $1.5-2.5 \mathrm{~cm}$ long, $0.3-$ $0.7 \mathrm{~cm}$ wide; side bracts $1.5-2.3 \mathrm{~cm}$ long, $0.2-0.7 \mathrm{~cm}$ wide, base cuneate, margin entire, apex long-attenuate, abaxial surface sericeous with whitish hairs, adaxial surface glabrescent; pedicels $0.4-0.6 \mathrm{~mm}$ long, hairy. Flowers pendulous; sepals unequal, 3 outer sepals ovate, $0.7-1.0 \mathrm{~cm}$ long $0.4-0.6 \mathrm{~cm}$ wide, margin entire, apex obtuse, glabrous or sericeous abaxilly, 2 inner sepals broadly obovate or broadly obcordate or orbicular, $0.7 \mathrm{~cm}$ long, $0.6 \mathrm{~cm}$ wide, margin entire, apex rounded or retuse, glabrous. Corolla campanulate, 4.1- 
$4.3 \mathrm{~cm}$ long, pure white, thickly membranous, midpetaline bands yellowish or brownish hirsute outside. Stamens included, equal, whitish; filaments $0.9-1.1 \mathrm{~cm}$ long; anthers oblong, 0.4 $0.6 \mathrm{~cm}$ long, parallel-sided, bases sagittate, apex sunken, deeply lobed, dehiscing lengthwise. Pistils included, longer than stamens, whitish. Ovary sunken in nectary disc, globose, apex abruptly narrowing into style base, glabrous. Styles $2.1 \mathrm{~cm}$ long, filamentous, glabrous. Stigma two-lobed, ca. $1.5 \mathrm{~mm}$ long. Fruit globose to subglobose, shiny reddish brown, 0.8$1.1 \mathrm{~cm}$ in diameter, glabrous. Seeds usually four, trigonousrounded, 5-6 mm long, black, glabrous.

Phenology: Flowering in July to September; fruiting in September to October.

Distribution: Thailand (Ubon Ratchathani), Vietnam (Lam Dong Province) (Fig. 2).

Ecology, habitat, and conservation status: Argyreia gyrobracteata grows on slopes, secondary forest, roadside, and bright preferred disturbed areas at elev. of about $400 \mathrm{~m}$ a.s.l., in association with Ficus sp., Lithocarpus sp., Mimosa sp., Musa sp., Dioscorea sp., Abrus sp., Bamboo sp., and Chromolaena sp. We found its distribution only in Lam Dong Province to date, consisting of at least sixty to seventy mature individuals in $>10$ populations. Consequently, Argyreia gyrobracteata is assessed here as Least Concern (LC) because its probable area of occupancy and the extent of occurrence are both greater than the limits of any of the threat categories (IUCN Standards and Petitions Committee, 2019).

Specimens examined: VIETNAM. Lam Dong Province: Da Huoai, along in Chuoi pass, $11^{\circ} 26^{\prime} 01,2^{\prime \prime} \mathrm{N}, 107^{\circ} 41^{\prime} 58,8^{\prime \prime} \mathrm{E}$, elev. 422 m, 17 Sep 2018, T. D. Binh 53; 17 Sep 2018, T. T. Bach, D. V. Hai, B. H. Quang, T. D. Binh, D. H. Son VK 7174 (HN!, KRIB!).

ORCID: Binh Duc TRAN 0000-0001-6658-0739; Bach The TRAN 0000-0002-4609-2575; Van Hai Do 0000-0001-78410585; Quang Hong BUI 0000-0001-6878-7514; Son Hoang DOAN 0000-0002-8776-3291; Han Ngoc LE 0000-00032657-5091; Thuy Thu NGUYEN 0000-0002-0921-5652; Sangmi EUM 0000-0002-5363-4870

\section{Acknowledgments}

We are grateful to the support by the Institute of Ecology and Biological Resources (IEBR), Vietnam Academy of Science and Technology (VAST) (project No. IEBR ĐT.7-20), the National Foundation for Science and Technology Development (NAFOSTED) (project No. NAFOSTED 106.03-2017.08), the Korea Research Institute of Bioscience and Biotechnology Research Initiative Program (Grant no. KGM4582013) and Project of Bioprospecting on Biological Materials of Vietnam (VON001.03/20-20).

\section{Conflict of Interest}

The authors declare that there are no conflicts of interest.

\section{Literature Cited}

Chitchak, N., P. Traiperm, G. Staples, P. Rattanakrajang and P. Sumanon. 2018. Species delimitation of some Argyreia (Convolvulaceae) using phenetic analyses: insights from leaf anatomical data reveal a new species. Botany 96: 217-233.

Cho, S. H., C. Phourin and Y. D. Kim. 2016. A Checklist for the Seed Plants of Cambodia. National Institute of Biological Resources, Ministry of Environment, Incheon. Pp. 64-66.

Fang, R-C. and G. Staples. 1995. Convolvulaceae. In Flora of China, Vol. 16. Gentianaceae through Boraginaceae. Wu, Z. Y. and P. H. Raven (eds.), Science Press, Beijing and Missouri Botanical Garden Press, St. Louis, MO. Pp. 271-325.

Gagnepain, F. and L. Courchet. 1915. Convolvulacées. In Flore Générale de l'Indochine, Vol. 4. Lecomte, H. (ed.), Masson, Paris. Pp. 228-313.

IUCN Standards and Petitions Committee. 2019. Guidelines for Using the IUCN Red List Categories and Criteria. Version 14. Prepared by the Standards and Petitions Committee. International Union for Conservation of Nature, Gland, $113 \mathrm{pp}$.

Kiew, R., R. C. K. Chung, L. G. Saw and E. Soepadmo. 2015. Flora of Peninsular Malaysia, Series II: Seed Plants, Vol. 5. Forest Research Institute Malaysia (FRIM), Malaysia, 319 pp.

Mabberley, D. J. 2017. Mabberley's Plant-Book: a Portable Dictionary of Plants, Their Classification and Uses. 4th ed. Cambridge University Press, Cambridge, 1102 pp.

Newman, M., S. Ketphanh, B. Svengsuksa, P. Thomas, K. Sengdala, V. Lamxay and K. Armstrong. 2007. A checklist of the vascular plants of Lao PDR. Royal Botanic Garden, Edinburgh, $394 \mathrm{pp}$.

Pham, H. H. 1999. An Illustrated Flora of Vietnam, Vol. 2. Tre Publishing House, Ho Chi Minh. Pp. 794-798.

Shalini, S., P. Lakshminarasimhan and D. Maity. 2017. A new combination and Lectotypification in Argyreia (Convolvulaceae). Nelumbo 59:145-148.

Staples, G. W. 2018. Flora of Cambodia, Laos and Vietnam, Vol. 36: Convolvulaceae. Royal Botanic Gardens, Pp. 25-78.

Staples, G., K. Phoutthavong, P. Traiperm and P. Pornpongrueng. 2014. A corrected and expanded checklist of Convolvulaceae 
from Lao PDR. Thai Journal of Botany 6: 79-87.

Staples, G. W. and P. Traiperm. 2010. Argyreia Lour. In Flora of Thailand 10(3). Santisuk, T. and K. Larsen (eds.), The Forest Herbarium, Bangkok. Pp. 337-371.

Traiperm, P., K. Fujikawa, N. Chitchak, P. Srisanga, C. Maknoi and G. Staples. 2019. A new species of Argyreia (Convolvu- laceae) from Myanmar. Willdenowia 49: 65-70.

Traiperm, P. and G. W. Staples. 2013. A new combination in Argyreia Lour. (Convolvulaceae). Adansonia 35: 359-363.

Traiperm, P. and G. W. Staples. 2016. Three new species of Argyreia (Convolvulaceae) from Thailand. Systematic Botany 41: 1020-1027. 